\title{
Pelatihan Metode Pembelajaran Bahasa Jawa Krama untuk Usia Dini Bagi Guru RA dan MI
}

\author{
Dwiana Asih Wiranti, Muhammad Misbahul Munir \\ Universitas Islam Nahdlatul Uiama Jepara \\ wiranti@unisnu.ac.id
}

Submitted: 18 April 2019; Revised: 7 July 2019; Accepted: 27 July 2019

Key word:

Learning method; Javanese language; early childhood

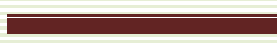

\section{Kata Kunci:}

Metode pembelajaran; Bahasa Jawa; Anak usia dini

\section{Abstract}

Javanese language is very important to students learn since early childhood. Where through Javanese language children can understand the positive value in the self-character. While learning Javanese etiquette in RA Miftahul Ulum and MI Miftahul Ulum 02 is still not optimal. So it is necessary to conduct training for teachers in RA Miftahul Ulum and MI Miftahul Ulum 02 in the lower classes related to the method of learning Javanese etiquette. Through this activity, the team provided training with demonstration methods about interesting learning methods, interactive and can be used to teach Javanese language especially "Krama" to early childhood. In this case early childhood is a low grade RA and MI student and training is given to teachers in RA Miftahul Ulum and MI Miftahul Ulum 02 in the lower class. This service activity has several stages which include, briefing and direction, implementation, monitoring, and evaluation. The results of this training received good appreciation from the partners. Partners actively participate in training activities. In addition, through practical activities, participants can practice the learning methods provided, so that participants are able to provide problems solving in the difficulties experienced by teachers in learning Javanese language for early childhood.

\section{Abstrak}

Bahasa Jawa krama sangat penting diajarkan kepada siswa sejak anak usia dini. Melalui bahasa Jawa krama anak bisa menumbuhkan nilai karakter positif dalam dirinya. Sementara pembelajaran bahasa Jawa krama di RA Miftahul Ulum dan MI Miftahul Ulum 02 masih belum maksimal. Maka perlu dilakukan sebuah pelatihan bagi guru di RA Miftahul Ulum dan MI Miftahul Ulum 02 kelas rendah terkait dengan metode pemmbelajaran bahasa Jawa krama. Melalui kegiatan ini, tim pengabdian akan memberikan pelatihan dengan metode demontrasi tentang metode-metode pembelajaran yang menarik, interaktif dan dapat digunakan untuk mengajarkan bahasa Jawa krama anak usia dini. Dalam hal ini anak usia dini merupakan siswa RA dan MI kelas rendah dan pelatihan diberikan kepada guru-guru di RA Miftahul Ulum dan MI Miftahul Ulum 02 kelas rendah. Kegiatan pengabdian ini memiliki beberapa tahapan yang meliputi, pembekalan dan pengarahan, implementasi, monitoring, dan evaluasi. Hasil pelatihan ini mendapat apresiasi yang baik dari pihak mitra, mitra berpartisipasi aktif dalam kegiatan pelatihan. Selain itu, melalui kegiatan praktik, peserta dapat mempraktikkan metode pembelajaran yang diberikan, sehingga peserta mampu memberikan solusi 
tentang kesulitan yang dialami oleh guru-guru dalam pembelajaran bahasa Jawa krama bagi anak usia dini.

\section{PENDAHULUAN}

Pendidikan untuk anak usia dini semakin diminati oleh masyarakat. Tingkat kesadaran pendidikan masyarakat Indonesia semakin meningkat apalagi bagi keluarga yang memiliki pendidikan sekolah tinggi. Kesibukan orang tua juga menjadi alasan meningkatnya jumlah peserta didik di lembaga PAUD. Kebanyakan dari mereka memilih percaya pada lembaga PAUD, untuk mendidik, mengasuh dan membimbing tumbuh kembang anak di usia dini agar lebih optimal. Oleh sebab itu, bebarapa lembaga PAUD kini saling bersaing. PAUD saat ini dituntut untuk mampu mengembangkan inovasi dan kreativitas sebaik mungkin untuk meningkatkan kualitas dan bisa menarik minat masyrakat. Baik dari segi input pendidik, pelayanan, prasana dan sarana maupun segi pembelajaran.

Mengajar di ranah anak usia dini selain harus penuh dengan kesabaran juga harus mampu menguasai materi, berani berinovasi dan berkreasi agar pembelajaran menarik bagi anak-anak. Pembelajaran untuk anak usia dini memang lebih bersifat learning by doing (bermain sambil belajar) sehingga, guru harus mampu tampil membawakan materi semenarik mungkin. Salah satu di antaranya adalah metode pembelajaran yang diterapkan oleh guru harus mampu membuat anak-anak merasa nyaman dengan bermain tetapi juga berproses dalam mempelajari sesuatu di dalamnya.

Selain harus mengikuti perkembangan kurikulum, proses pembelajaran PAUD juga harus mampu untuk mengoptimalkan potensi daerah agar budaya dan kekayaan lokal bisa ditanamkan kepada anak sejak usia dini. Hal ini tentu menjadi sangat penting karena anak adalah aset penerus bangsa. Termasuk dalam mempelajari bahasa Jawa krama bagi anak usia dini. Hal ini juga pernah diteliti dan menunjukkan bahwa bahasa daerah (termasuk di dalamnya bahasa Jawa berkedudukan sebagai (1) lambang kebanggaan daerah, (2) lambang identitas daerah, dan (3) alat perhubungan di dalam keluarga dan masyarakat daerah (Turaeni, 2006) dan (Arafik \& Rumidjan, 2017). Oleh sebab itu, mempelajari bahasa Jawa terutama bahasa Jawa karma bagi anak usia dini sangat penting.

Tidak hanya dalam kalangan PAUD. Anak usia dini adalah mereka yang berusia 0-8 tahun (Suyadi, 2013). Sejalan dengan pernyataan tersebut, penelitian juga 
menyatakan hal yang sama bahwa anak usia dini berusia sejak 0-8 tahun (Barbour, 1992). Siswa pada tingkat sekolah dasar yang duduk dibangku kelas satu sampai dengan kelas dua termasuk dalam kategori anak usia dini. Usia kelas rendah pada sekolah dasar perlu sekali adanya pembelajaran budaya lokal, khususnya terkait dengan pembelajaran bahasa Jawa khususnya bahasa Jawa krama perlu untuk dilestarikan.

Penelitian yang telah dilakukan mengungkap bahwa Bahasa Jawa sedang mengalami pergeseran ke bahasa Indonesia (Munandar, 2013). Penguasaan bahasa Jawa sudah terlebih dahulu dikuasai masyarakat Jawa. Hal tersebut berpengaruh pada saat mereka menggunakan bahasa Indonesia (Pitoyo, 2017). Pada mahasiswa, secara sengaja maupun tidak, ketika berbicara menggunakan bahasa Indonesia mereka akan mencampur dengan bahasa Jawa. Begitu juga sebaliknya ketika menggunakan bahasa Jawa sebagaian besar dari mereka akan mencampur menggunakan bahasa Indonesia. Tidak hanya pada mahasiswa, siswa pun juga mengalami hal yang sama. Hasil Penelitian menemukan bahwa siswa juga melakukan pencampuran bahasa Jawa dan bahasa Indonesia dalam karangannya (Putri, Widodo, \& Suyanto, 2017).
Bahasa Jawa merupakan bahasa yang memiliki tingkat tutur atau unggahungguh. Sampai saat ini unggah-ungguh basa masih digunakan oleh sebagian besar penutur berbahasa Jawa karena memiliki nilai karakter yang sangat dalam (Sutardjo, 2008). Lebih lanjut unggah-ungguh basa atau undha usuk yang lazim pula disebut dengan tingkat tutur bahasa merupakan suatu kekayaan budaya yang dimiliki oleh beberapa suku di Indonesia, terutama dimiliki oleh suku Jawa (Harjawiyana \& Supriya, 2001).

Masyarakat di Kabupaten Kudus menggunakan bahasa lokal sebagai alat komunikasi sehari-hari yaitu bahasa Jawa. Akan tetapi, dewasa ini pengguna bahasa jawa bagi anak usia usia dini sudah mulai berkurang. Kaum muda memilih bahasa sebagai alat ekspresinya pada ranah rumah dan ranah persahabatan. Sebagaimana yang ditunjukkan oleh hasil penelitian bahwa generasi muda Jawa lebih banyak menggunakan Bahasa Indonesia daripada Bahasa Jawa baik pada ranah rumah maupun persahabatan. Para orang tua muda saat ini lebih banyak yang mengajarkan bahasa Indonesia sebagai alat komunikasi sehari-hari bukan bahasa Jawa (Suharyo, t.t.).

Berdasarkan hasil observasi melalui wawancara kepada beberapa wali murid di RA Miftahul Ulum maupun MI Miftahul 
Ulum 02, Bahasa Indonesia lebih banyak digunakan karena dirasa lebih mudah diajarkan, ada pula yang beralasan karena tidak bisa menggunakan bahasa Jawa apalagi untuk bahasa Jawa krama. Selain itu, kesulitan yang dialami siswa dalam berbahasa Jawa umumnya terdapat pada keterampilan menggunakan bahasa Jawa krama alus. Banyak ditemukan bahwa siswa mengalami kesulitan menggunakan kaidah tata bahasa, pemilihan kosa kata, dan penyusunan kalimat efektif (Sukoyo \& Suwandi, 2013).

Beberapa guru RA Miftahul Ulum menjelaskan bahwa penggunaan bahasa Jawa krama bagi anak usia dini tergolong sulit. Pasalnya, ada perbedaan kata sesuai dengan lawan tutur. Di samping itu, guru RA Miftahul Ulum juga mengaku mengalami kesulitan dalam mengajarkan bahasa Jawa krama kepada anak usia dini karena gurunya pun tidak menguasai bahasa Jawa krama.

Sementara itu, hasil wawancara dengan salah seorang guru di MI Miftahul Ulum 02 (Ibu Hartini), menunjukkan bahwa dalam pembelajaran guru sudah mengupayakan untuk mengajarkan bahasa Jawa krama kepada anak-anak. Hanya saja baru sebatas kata-kata tertentu. Seperti terkadang mengganti kata 'terima kasih' menjadi 'matur nuwun', kata 'iya' menjadi 'nggih', kata tidak menjadi 'boten'.
Penggunaan kata-kata tertentu ini dilakukan hanya sesekali dan tidak secara kontinyu karena dalam kegitan sehari-hari, guru tetap menggunakan bahasa Indonesia. Pembentukan karakter seseorang bisa diolah dengan baik melalui bahasa Jawa krama. Ketika anak mampu berbahasa Jawa krama dengan baik maka secara tidak langsung mereka akan belajar untuk lebih mampu untuk menghormati orang yang lebih tua dan menyayangi teman sebaya dengan tutur bahasa yang lebih elok. Jika tutur bahasa anak sudah bisa dijaga sejak dini, maka di waktu kedepan dia akan terbiasa untuk mampu mengendalikan diri (Laila, 2016).

Melihat situasi dan kondisi tersebut, perlu adanya pembelajaran bahasa Jawa untuk anak usia dini terlebih bahasa Jawa krama. Generasi penerus tidak akan bisa menggunakan bahasa Jawa dengan baik dan benar. Padahal dalam bahasa Jawa tersirat nilai karakter yang sangat dalam. Pembiasaan berbahasa Jawa bagi siswa perlu dimulai dari guru-guru. Oleh karena itu, perlu adanya pelatihan pembelajaran bahasa Jawa krama untuk anak usia dini bagi guru guru RA Miftahul Ulum dan MI Miftahul Ulum 02 kelas rendah.

Tujuan dari pelatihan ini adalah (1) Guru bisa meningkatkan perbendaharaan kata dalam bahasa Jawa krama sesuai denga tingkat tutur yang benar; (2) guru 
dapat mengajarkan bahasa Jawa krama melalui lagu anak-anak. Guru akan diberikan contoh lagu-lagu yang berkaitan dengan bahasa Jawa krama, kemudian dilatih bagaimana cara menyalurkan kepada anak agar anak mengenal bahasa Jawa krama dan mampu menerapkannya dengan baik.

\section{METODE}

Pelaksaan program pengabdian ini dilakukan dengan mendemonstrasikan metode-metode pembelajaran bahasa Jawa krama kepada peserta. Menjelaskan tahaptahap penerapan metode dan teknik-tekik yang dapat diterapkan oleh para peserta dalam pembelajaran di kelas. Selain itu, tim juga akan menggunakan metode pemodelan, dengan cara salah satu tim akan berperan seolah menjadi guru dan mempraktekkan metode yang diajarkan. Melalui metode ini peserta akan lebih jelas dalam menyerap pelatihan metode pembelajaran bahasa Jawa krama yang dilatihkan oleh tim pengabdian. Tentunya, tim juga membuka diskusi agar bisa menampung pertanyaan dan memberikan penjelasan serta solusi bagi peserta yang mengalami kebingungan dalam penerapan metode pembmelajaran yang dilatihkan.

\section{Tahapan Pelaksanaan}

Program pengabdian dilaksanakan melalui pelatihan metode pembelajaran bahasa Jawa krama bagi guru RA dan MI kelas rendah ini memiliki tahapan pembekalan dan pengarahan, implementasi, monitoring, dan evaluasi. Masing-masing tahapan tersebut dijelaskan sebagai berikut.

a. Pembekalan dan Pengarahan

Pembekalan dan pengarahan menjadi tahap pertama dalam pelaksanaan pengabdian ini. Dimana pembekalan merupakan kegiatan pemberian materi terkait dengan metode pembelajaran yang diajarkan kepada mitra. Metode pembelajaran bahasa Jawa krama yang diajarkan meliputi: lagu, bermain peran dengan boneka tangan, role playing, dan sambung kata melalui game.

b. Implementasi

$\begin{array}{clc}\text { Tahap } & \text { kedua } & \text { adalah } \\ \text { implementasi. } & \text { Kegiatan } & \text { dalam }\end{array}$
tahap ini peserta mempraktikkan metode yang telah diajarkan dengan cara peer teaching. Masing-masing peserta menerapkan metode pembelajaran yang dilatihkan oleh tim pengabdian.

c. Monitoring

Monitoring dilakukan oleh tim pengabdian dengan cara memantau hasil implementasi oleh peserta 
pengabdian dan penggunaan alat peraga dari tim. Dalam tahap ini, tim pengabdian memberi arahan kepada peserta dalam mengimplementasikan metode pembelajaran bahasa Jawa krama.

d. Evaluasi

Tahap akhir dalam pelaksanaan pengabdian ini adalah evaluasi. Tim pengabdian memberi evaluasi terhadap metode pembelajaran yang sudah dipraktikkan oleh para peserta. Selain itu, tim juga memberikan penilaian, menyampaikan kekurangan, koreksi dan perbaikan dari hasil praktik.

\section{Partisipasi Mitra}

Mitra dalam hal ini adalah RA Miftahul Ulum dan MI Miftahul Ulum 02 merupakan lembaga yang telah bersedia bekerja sama dengan tim pengabdian Unisnu Jepara. Mitra terdiri dari guru RA dan MI yang total berjumlah 30 orang. Selain itu, mitra bersedia berpartisipasi aktif dan menyediakan tempat dalam pelaksanaan pelatihan metode pembelajaran bahasa Jawa krama serta bersedia mematuhi teknis pelaksanaan program pengabdian.
Mitra yang merupakan guru RA Miftahul Ulum dan MI Miftahul Ulum 02 akan bertindak sebagai peserta. Dimana mereka nantinya akan menyimak penjelasan dan arahan dari tim pengabdian. Kemudian, melakukan praktik dalam pelatihan didampingi oleh tim pengabdian. Selanjutnya mereka akan mendapat evaluasi dan perbaikan agar dapat menguasai metode dengan optimal.

\section{HASIL}

Program pengabdian yang dilakukan melalui pelatihan metode pembelajaran bahasa Jawa krama bagi guru RA dan MI kelas rendah ini mendapat respon positif dari peserta pelatihan. Kegitan pelatihan dilakukan dalam beberapa tahapan yang meliputi pembelakalan dan pengarahan, implementasi, monitoring, evaluasi dan feedback. Tahap pembelakan dan pengarahan serta implementasi telah dilakukan pada hari Senin tanggal 14 Mei 2018 di MI Miftahul Ulum 02, Desa Honggosoco, Kecamatan Jekulo, Kabupaten Kudus. Peserta pelatihan terdiri dari guru MI dan RA Miftahul Ulum yang terdiri dari 30 peserta. Secara rinci kegiatan pelatihan ini dideskripsikan sebaagai berikut. 


\section{Pembekalan dan Pengarahan}

Pada kegiatan ini tim pengabdian memberikan pembelakalan dengan cara memberikan materi tentang metode pembelajaran bahasa Jawa krama yang bisa diajarkan baik di tingkat RA maupun MI. Materi ditayangkan melalui power point juga dicetak dan dibagikan kepada peserta pengabdian.

Metode pembelajaran bahasa Jawa krama yang diajarkan meliputi, metode role playing, metode bermain peran dengan boneka tangan, metode tebak kata melalui game dan metode lagu. Tim pengabdian menjelaskan metode-metode tersebut kemudian dilanjutkan dengan pengarahan. Selanjutnya tim pengabdian mengemas kegiatan secara interaktif dalam bentuk diskusi. Dimana tim memberikan arahan dan petunjuk terkait langkah-langkah yang harus dilakukan oleh peserta dalam menerapkan metode yang telah dijelaskan. Peserta diperbolehkan untuk diskusi dan bertanya kepada tim.

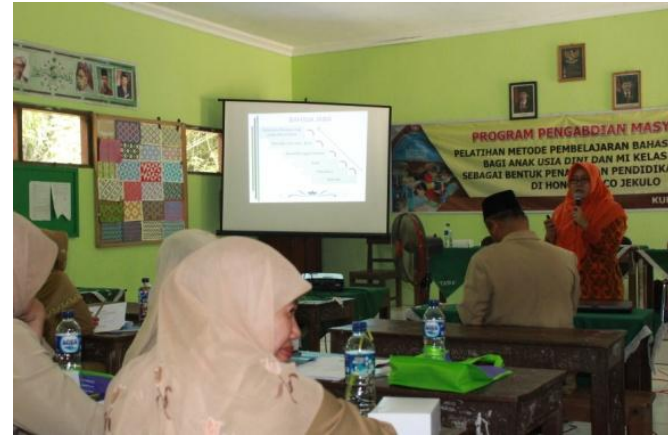

Gambar 1. Kegiatan pembekalan dan pengarahan

a. Metode role playing merupakan metode dengan model aplikasi langsung. Dimana peserta didik nanti akan memerankan salah satu tokoh seperti, bapak, ibu, anak, kakak, adik, penjual, guru, dan lain sebagainya. Hampir sama dengan metode role playing, metode bermain peran menggunakan boneka tangan perbedaannya hanya pada media. Jika metode role playing peserta didik memerankan secara langsung, sedangkan metode bermain peran menggunakan boneka tangan peserta didik mempraktikkan menggunakan boneka tangan. Boneka tangan yang disediakan oleh tim pengabdian berupa boneka tangan karakter keluarga seperti kakek, nenek, ayah, ibu, anak perempuan, dan anak laki-laki.

b. Metode tebak kata merupakan peralihan dari bentuk soal 
tradisional yang sering muncul dalam soal bahasa Jawa tingkat Sekolah Dasar. Contohnya, "Basa kramane adus yaiku..." Bentuk soal demikian idealnya sudah tidak boleh diberikan kepada peserta didik. Soal bahasa Jawa harus kontekstual. Jadi, dalam tujuan yang sama soal bisa dirubah dengan menyertakan konteks. Bisa berupa percakapan rumpang. Meskipun bentuk soal tradisional seperti yang dicontohkan tidak boleh diberikan, tetapi tetap bisa digunakan dalam pembelajaran. Cara tersebut dinamakan metode tebak kata.

c. Metode lagu menjadi hal yang sangat menarik untuk pembelajaran anak usia dini. Guru juga bisa mengajarkan bahasa Jawa krama melalui lagu. Seperti lagu yang dibuat oleh tim pengabdian untuk dijadikan contoh, dengan lirik sebagai berikut.

Siji loro telu

Astane sedheku

Mirengaken bu guru menawi

didangu

Papat nuli lima

Lenggahe sing tata

Aja padha sembrana

Mundhak ora bisa
Iki lho tanganku

Astane simbahku

Hla yen iki sukuku

Samparane bapakku

Iki lho rambutku

Rikmane ibuku

Hla yen iki mripatku

Netrane bu guru

Iki lho bathukku

Palarapan bapakku

Hla yen iki pipiku

Pangarasane yayu

\section{Implementasi}

Pada tahap implementasi, peserta pelatihan sangat antusias mempraktikkan metode yang telah diajarkan dengan cara pear teaching. Masing-masing peserta mengimplementasikan metode pembelajaran yang dilatihkan oleh tim pengabdian. Ketika peserta mengimplementasikan metode yang diajarkan, tim pengabdian melakukan monitoring. Peserta diberikan alat peraga oleh tim sesuai dengan alat yang digunakan dalam menerapkan metode yang dilatihkan oleh tim pengabdian. Suasana menjadi semakin ramai dan menyenangkan ketika peserta tertawa saat melihat peserta 
lain mempraktikkan sebagai anakanak.

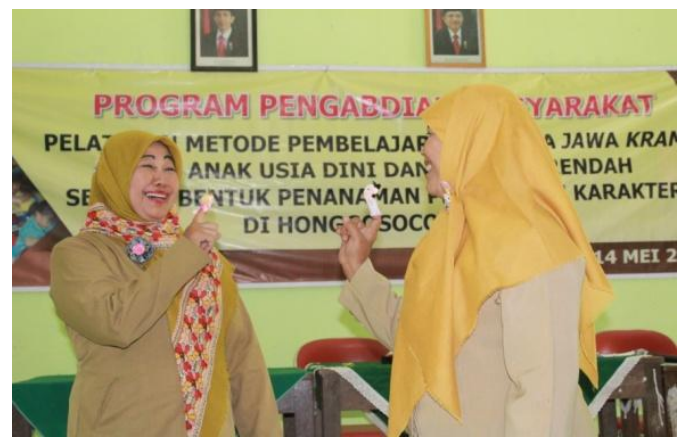

Gambar 2. Kegiatan pearteaching

\section{Monitoring}

Monitoring dilakukan oleh tim pengabdian dengan cara memantau hasil implementasi oleh peserta pengabdian dan penggunaan alat peraga dari tim. Dalam tahap ini, tim pengabdian memberi arahan kepada peserta dalam mengimplementasikan metode pembelajaran bahasa Jawa krama. Hal ini sudah dilakukan pada tanggal 14 Mei 2018 bersama dalam rangkaian pembekalan dan implentasi. Dimana tim pengabdian memantau hasil implementasi secara pearteaching .

Akan tetapi, tim pengabdian juga perlu memantau sejauh mana kebermanfaatan peraga yang diberikan kepada peserta dalam menunjang implementasi metode pembelajaran bahasa Jawa krama ketika diajarkan di dalam kelas. Kegiatan ini dilakukan pada tanggal 21 Juli 2018, setelah libur hari raya Idul fitri. Melalui tahap ini, tim pengabdian memantau dan mengamati proses pembelajaran yang dilakukan oleh guru di dalam kelas dengan mengaplikasikan metode pembelajaran yang telah dilatihkan kepada peserta.

\section{Evaluasi dan Feedback}

Tahap akhir dalam pelaksanaan pengabdian ini adalah evaluasi. Tim pengabdian memberi evaluasi terhadap metode pembelajaran yang sudah dipraktikkan oleh para peserta. Selain itu, tim juga memberikan apresiasi, menyampaikan kekurangan, koreksi dan perbaikan dari hasil praktik. Melalui evaluasi yang dikemas dalam bentuk diskusi ini pemahaman peserta menjadi lebih optimal dan mampu untuk memperbaiki kekurangan, sehingga dalam penerapan di kelas selanjutnya akan merasa mudah dan optimal.

Tidak hanya tim pengabdian yang memberi evaluasi. Akan tetapi, peserta juga memberikan feed back berupa masukan, kritik, keluhan, bahkan pertanyaan terkait dengan program pelatihan yang diberikan kepada peserta. Masukan yang ditampung dari peserta pelatihan diantaranya, mereka menginginkan adanya pelatihan sejenis tetapi beda 
materi. Selain itu, mereka berharap akan sering dilakukan diskusi dengan tim pengabdian Unisnu terkait dengan pembelajaran agar permasalahan lain selain dalam metode pembelajaran bahasa Jawa juga dapat diatasi. Mitra juga berharap kegiatan dan kerjasama dengan pihak Unisnu bisa terus berlanjut dengan melakkukan berbagai kegiatan baik yang serupa maupun kegiatan yang lain. Dengan adanya feed back ini, maka tim pengabdian masukan yang akan dapat dijadikan perbaikan dan pengembangan dalam pemberian pelatihan yang lain.

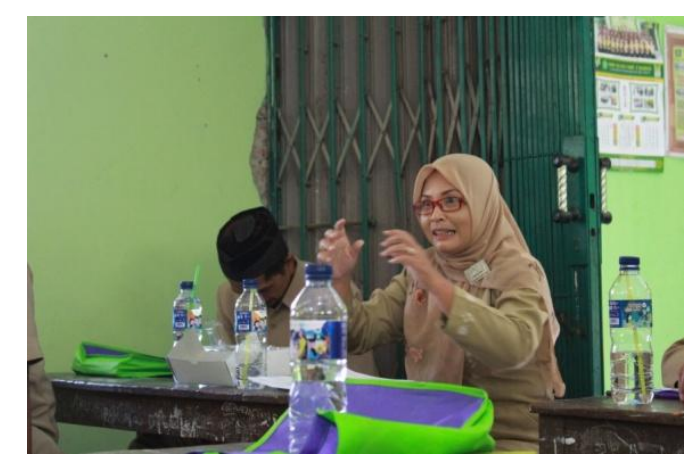

Gambar 3. Feedback dari peserta

\section{PEMBAHASAN}

Keberhasilan program pengabdian Pelatihan Metode Pembelajaran Bahasa Jawa Krama untuk Usia Dini bagi Guru RA dan MI dilihat dari kemampuan guru melakukan metode-metode yang telah dilatihkan dan dipraktikkan kepada siswanya. Setelah itu dilihat sejauh mana siswa memahami dan mengingat Bahasa Jawa yang telah diajarkan oleh guru.

1. Tingkat kemampuan guru melakukan metode lagu, dan tingkat pemahaman siswa. Guru yang dilatih dalam pengabdian ini sudah mulai memahami bagaimana tips melakukan pembelajaran Bahasa Jawa. Praktik penggunaan metode lagu yang dilakukan guru disambut antusias oleh siswa. Guru menyanyikan lagu sambil mempraktikkan gerakan yang sesuai dengan lirik lagu. Siswa dengan mudah memahami dan mereplikasi gerakan tersebut. Pengamatan yang dilakukan adalah siswa memahami kosakatakosataka Bahasa Jawa baru. Metode lagu atau nyanyian membuat siswa lebih ekspresif baik bahagia atau sedih sesuai dengan nada dan lirik lagu. Metode ini juga memudahkan siswa untuk memahami materi baru yang diajarkan oleh guru (Gunawan, Yuline, \& Halida, 2014).

2. Tingkat kemampuan guru dan pemahaman siswa melalui metode bermain peran (role playing) dengan boneka tangan. Guru terlebih dahulu menceritakan ilustrasi cerita yang akan ditirukan kembali oleh siswa. Hasil pelaksanaan metode ini adalah para guru aktif mencari ilustrasi cerita serta menjelaskan bagaimana siswa harus 
menirukan

adegan/ilustrasi.

Pembelajaran Bahasa Jawa dengan model ini efektif untuk menggali kemampuan siswa merangkai kalimat berdasarkan kosakata yang dimilikinya. Pembelajaran model ini diberikan kepada siswa kelas rendah, sehingga harapannya peserta didik akan lebih mudah dalam menyusun kalimat ketika bermain peran (Siska, 2011).

3. Tingkat kemampuan guru dan pemahaman siswa berdasarkan metode tebak kata melalui game dan metode lagu. Guru menanyakan bahasa krama dari suatu kata kepada peserta didik. Melalui metode ini, guru bisa mendeteksi peserta didik mana yang sudah mengetahui, mana yang belum, atau mana yang keliru. Hal ini dilakukan agar pada saat itu juga guru bisa langsung mengarahkan jawaban yang benar dan menjelaskannya. Peserta didik secara langsung juga akan mendapatkan kosa kata baru dalam pembelajaran bahasa Jawa krama. Metode ini akan lebih menarik jika dikemas dalam bentuk permainan. Guru bisa membuat kelompok yang terdiri dari beberapa peserta didik. Kemudian masing-masing kelompok berlomba untuk menebak kosa kata sebanyakbanyaknya dengan benar. Kelompok yang paling banyak menjawab dengan benar, dialah yang menjadi pemenang. Hasil ini selaras dengan temuan bahwa permainan tradisional dapat meningkatkan keterampilan sosial anak usia dini. (Rahayu, Hamid, \& Sutini, 2018)

Tim pengabdian juga memantau sejauh mana kebermanfaatan peraga yang diberikan kepada peserta dalam menunjang implementasi metode pembelajaran bahasa Jawa krama yang telah diajarkan. Harapannya melalui tahap ini, peserta menjadi semakin memahami dan mampu mengimplentasikan metode pembelajaran yang dilatihkan dengan benar dan mampu mencapai kompetensi yang diharapkan. Hasilnya, melalui evaluasi ini pemahaman peserta menjadi lebih optimal dan mampu untuk memperbaiki kekurangan, sehingga nampak dalam penerapan di kelas pembelajaran lebih optimal. Siswa juga antusias dalam pembelajaran karena guru lebih banyak memberikan variasi metode pembelajaran bahasa Jawa.

Tidak hanya tim pengabdian yang memberi evaluasi. Akan tetapi, peserta juga memberikan feedback berupa masukan, kritik, keluhan, bahkan pertanyaan terkait dengan program pelatihan yang diberikan kepada peserta. Feedback yang diberikan oleh mitra berisi masukan yang akan dapat dijadikan 
perbaikan dan pengembangan dalam pemberian pelatihan yang lain terutama dalam hal kebahasaan atau mengenai pendidikan anak usia dini. Demikian juga yang didapat dari hasil penelitian bahwa .

Hasil keseluruhan dari kegiatan ini, peserta terlihat semakin memahami, menguasai dan mampu mengimplentasikan metode pembelajaran yang dilatihkan dengan benar. Hal ini mendapat respon yang baik dari antusias siswa ketika pembelajaran dan peserta didik mampu mencapai kompetensi yang diharapkan.

\section{SIMPULAN DAN SARAN}

\section{a. Kesimpulan}

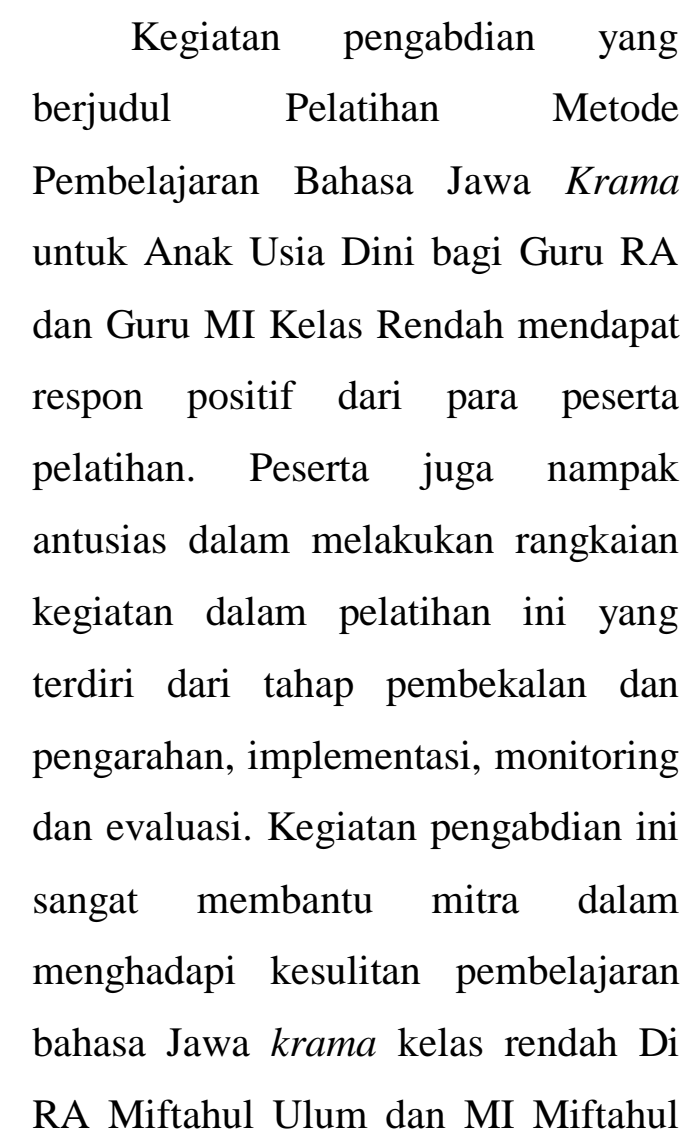

Ulum 02 Desa Honggosoco, Kecamatan Jekulo, Kabupaten Kudus.

\section{b. Saran}

Berdasarkan hasil evaluasi kegiatan pengabdian, peserta memberi saran bahwa akan lebih baik jika kegiatan pelatihan dilakukan secar berkelanjutan. Artinya, pelatihan tidak hanya untuk materi metode pembelajaran bahasa Jawa krama saja. Akan tetapi juga untuk mata pelajaran yang lain. Kemudian, pihak mitra menginginkan adanya kerjasama yang berlanjut antara mitra dengan Unisnu. Tim pengabdian juga menyarankan bahwa kegiatan pelatihan tentang metode pembelajaran bagi guru perlu banyak dilakukan. Sehingga guru akan mempunyai referensi metode pembelajaran ang lebih banyak. Selain itu, guru juga akan merasa terbantu dalam mengatasi berbagai permasalahan dalam mengajar di kelas.

\section{UCAPAN TERIMA KASIH}

Ucapan terima kasih kami sampaikan kepada Lembaga Penelitian dan Pengabdian Unisnu Jepara atas fasilitasi yang diberikan sehingga pengabdian ini dapat terlaksana. Kepala RA Miftahul Ulum dan MI Miftahul Ulum Kecamatan Jekulo, Kudus atas kerjasama dan 
dukungan sehingga pengabdian ini dapat terlaksana. Guru-guru dan siswa dari RA dan MI mitra yang sangat antusias dan penuh semangat selama program berlangsung.

\section{DAFTAR PUSTAKA}

Arafik, M., \& Rumidjan, R. (2017). Profil Pembelajaran Unggah-ungguh Bahasa Jawa di Sekolah Dasar. Sekolah Dasar: Kajian Teori dan Praktik Pendidikan, 25(1), 55-61.

Barbour, N. B. (1992). Early childhood gifted education: A collaborative perspective. Journal for the Education of the Gifted, 15(2), 145-162.

Gunawan, V., Yuline, \& Halida. (2014). Peningkatan Kemampuan Pengucapan Bahasa Inggris Melalui Metode Bernyanyi Pada Anak Usia 5-6 Tahun. Jurnal Pendidikan Dan Pembelajaran, 3(8). Diambil dari http://jurnal.untan.ac.id/index.php/j pdpb/article/view/6723

Harjawiyana, H., \& Supriya, T. (2001). Kamus unggah-ungguh basa Jawa. Kanisius.

Laila, W. N. (2016). Konsep Diri Remaja Muslim Pengguna Bahasa Jawa
Krama. Profetik: Jurnal Komunikasi, 9(2), 61-69. https://doi.org/10.14421/pjk.v9i2.1 206

Munandar, A. (2013). Pemakaian Bahasa Jawa dalam Situasi Kontak Bahasa di Daerah Istimewa Yogyakarta. Jurnal Humaniora, 25(1), 92-102. https://doi.org/10.22146/jh.v25i1.1 819

Pitoyo, A. (2017). Interferensi Bahasa Jawa ke dalam Bahasa Indonesia Mahasiswa Program Studi Pendidikan Bahasa dan Sastra Indonesia dalam Perkuliahan Keprotokolan. Jurnal Pena Indonesia, 3(2), 185-200.

Putri, N. E., Widodo, M., \& Suyanto, E. (2017). Interferensi Leksikal Bahasa Jawa ke dalam Bahasa Indonesia pada Karangan Siswa. Jurnal Kata (Bahasa, Sastra, dan Pembelajarannya), 5(2, April).

Rahayu, D., Hamid, S. I., \& Sutini, A. (2018). Peningkatan Keterampilan Sosial Anak Usia Dini Melalui Permainan Tradisional. Cakrawala Dini: Jurnal Pendidikan Anak Usia Dini, $7(2)$. https://doi.org/10.17509/cd.v7i2.10 527 
Siska, Y. (2011). Penerapan metode bermain peran (role playing) dalam meningkatkan keterampilan sosial dan keterampilan berbicara anak usia dini. Jurnal Edukasi. UPI. Edisi Khusus, 2.

Suharyo, S. (t.t.). Nasib Bahasa Jawa dan Bahasa Indonesia dalam Pandangan dan Sikap Bahasa Generasi Muda Jawa. Nusa: Jurnal Ilmu Bahasa dan Sastra, 13(2), 244-255.

Sukoyo, J., \& Suwandi, S. (2013). Hubungan Antara Penguasaan Tingkat Tutur Dan Sikap Ekstrovert Dengan Keterampilan Berbicara Krama Alus Mahasiswa Program Studi Pendidikan Bahasa Dan Sastra Jawa Universitas Negeri Semarang. Jurnal Pendidikan Bahasa dan Sastra, 1(1), 97-107.

Sutardjo, I. (2008). Kajian Budaya Jawa. Jurusan Sastra Daerah, Fakultas Sastra dan Seni Rupa, Universitas Sebelas Maret.

Suyadi. (2013). Konsep dasar PAUD. PT Remaja Rosdakarya.

Turaeni, T. (2006). Penggunaan Bahasa Indonesia dalam Keluarga Muda Etnis Bali. SEMIOTIKA: Jurnal
Ilmu Sastra Dan Linguistik, 7(1), 68-73. Diambil dari https://jurnal.unej.ac.id/index.php/S EMIOTIKA/article/view/6972 